\title{
Uma teoria feminista-vegana: a política sexual da carne
}

\begin{abstract}
A política sexual da carne: a relação entre carnivorismo e a dominância masculina.
\end{abstract}

ADAMS, Carol.

Tradução de Cristina Cupertino.

São Paulo: Alaúde, 2012. 350p.

Carol Adams pode ser apresentada como uma escritora feminista e ativista pelos direitos dos animais. Uma escritora atuante e versátil, que publicou suas ideias sobre o vegetarianismo, os direitos dos animais, a violência doméstica e o abuso sexual em artigos, livros, revistas, sites e enciclopédias. Dos livros que escreveu, há dois que tratam, particularmente, da ligação entre a opressão das mulheres e a dos animais não humanos: The sexual politics of meat: a feminist-vegetarian critical theory (1990) e The pornography of meat (2003). Dentre outros livros, pode-mos citar: Ecofeminism and the sacred (1993); Neither man nor beast: feminism and the defen-se of animals (1994); Animals and women: feminist theoretical explorations, com Josephine Donovan (1995); Violence against women and children: a christian theological sourcebook, com Marie Fortune (1995); The inner art of vegetarianism (2000); Prayers for animals (2004); Meditations on the inner art of vegetarianism (2001); e o prefácio de Sister species: women, animals, and social justice (2011).

Finalmente, depois de vinte anos após a publicação da primeira edição, a obra $A$ política sexual da carne é lançada no Brasil, ganhando 
um novo subtítulo: A relação entre carnivorismo e a dominância masculina, lembrando que o original teve como subtítulo: "A feminist-vegetarian critical theory", o que nos fornece um importante dado para questionarmos: As teorias feministas são aceitas no Brasil? É importante essa questão, pois o subtítulo do original sugere uma proposta teórica feminista, e sua negação ou mesmo ocultação representa, por outro lado, o descaso. A questão colabora para pensarmos que a resposta é negativa, existe uma falta das traduções feministas ou mesmo a escassez desses textos.

Através da leitura de textos literários e filosóficos, Adams propõe e discute uma análise mais apurada das ligações entre feminismo e vegetarianismo, bem como a relação entre o patriarcado e a prática de comer carne. Descreve o que chama a estrutura do "referencia ausente", sendo o que, nesse contexto, separa a carne e o animal morto a partir do produto final. A função do referencial ausente é manter a carne separada de qualquer ideia de que ela era um animal. As mulheres são referenciais ausentes em nossa cultura também, sendo vistas como um corpo a ser consumido e usado pela publicidade e de muitos outros modos. A teoria feminista é importante, porque nos ajuda a entender 0 modus operandi de como as opressões estão interligadas. O livro mostra como os animais são consumidos, literalmente, e como as mulheres são consumidas, visualmente, através de acesso sexual de seus corpos estupráveis.

A Política Sexual da Carne discute como, especialmente em tempos de escassez, muitas vezes as mulheres dão aos homens a carne, a qual eles consideram ser o "melhor" dos alimentos

O livro é dividido em três partes e nove capítulos. A primeira parte do livro, intitulada "Os textos patriarcais da carne", é dividida em quatro capítulos que são: "A política sexual da carne"; "Estupro de animais, retalhamento de mulheres"; "Violência mascarada, vozes silenciadas" e "A palavra se fez carne". A autora cunhou o termo "antropornografia", que significa mostrar animais como seres que pedem para serem comidos, uma perspectiva que, segundo ela, é um dos alicerces do patriarcado. Desse modo, a "antropornografia" é o conceito central, criado nessa primeira parte, que está no bojo da análise dos textos referentes à carne que compõem a sequência.

Carol Adams (2011) pergunta-nos se somos predadores ou não. Ela diz que, na tentativa de nos ver como seres naturais, algumas pessoas argumentam que os seres humanos são simplesmente predadores como alguns outros animais, simplificando e coisificando o corpo dos animais. Para a autora, o vegetarianismo é visto como não natural, enquanto o carnivorismo dos outros animais é transformado em paradigmático. Os animais se tornam coisas a serviço dos prazeres carnais, ditos naturais, pelos machos humanos, ditos predadores. Assim, os direitos animais são criticados e as desanalogias mais profundas com animais carnívoros permanecem intocadas porque a noção de seres humanos como predadores é consoante com a ideia de que precisamos comer carne. Diz a autora que, de fato, o carnivorismo é verdadeiro para apenas $20 \%$ dos animais não humanos, segundo a biologia atual.

Em A política sexual da carne, ela nomeou esse processo conceitual no qual o animal desaparece da estrutura do referencial ausente. Animais em nome e corpo são feitos ausentes como animais para que a carne exista. Se animais estão vivos, eles não podem ser carne. Logo, um cadáver substitui o animal vivo, e animais se tornam referenciais ausentes. Os animais são feitos ausentes através da linguagem, que renomeia cadáveres antes que consumidores e consumidoras participem em comê-los. O referencial ausente nos permite esquecer do animal como uma entidade independente. O assado no prato é desencorporado do porco o qual ela ou ele um dia foi. O referencial ausente resulta do cativeiro ideológico e o reforça: a ideologia patriarcal estabelece o padrão cultural de ser humano e de ser animal. Na política sexual da carne, é simplesmente impossível ser homem sem comer carne.

A segunda parte do livro, intitulada "Da barriga de Zeus", está dividida em três capítulos, os quais são, respectivamente: "Textos desmembrados, animais desmembrados", "O monstro vegetariano de Frankenstein" e "O feminismo, a Grande Guerra e o vegetarianismo moderno". Os capítulos da segunda parte abordam alguns romances nos quais aparecem personagens vegetarianas. A autora entende que a teoria feminista é a base para essa crítica literária, já que a história da carne é feita não somente de textos de carne, mas principalmente do apagamento da palavra feminista e vegetariana. Diz ela: "Mudar um animal do seu estado original, fazendo-o se transformar em comida, compara-se a mudar um texto do seu estado original, fazendo-o se transformar em algo mais agradável" (p. 148). Para as escritoras abordadas, a questão do vegetarianismo tornase uma mediação feminina complexa entre as relações de poder estabelecidas tanto no especismo quanto no sexismo.

A terceira parte do livro: "Coma arroz, tenha fé nas mulheres", está dividida em "A distorção 
do corpo vegetariano" e "Por uma teoria crítica feminista-vegetariana". Nessa parte, ela lança sua proposta, que é a de uma teoria crítica feminista-vegetariana, argumentando que a defesa dos animais é a teoria e o vegetarianismo é a prática, assim como o feminismo é a teoria e o vegetarianismo faz parte de suas práticas, ou seja, para o leque de práticas feministas, é necessário pensar a carne como elemento viril da cultura patriarcal. O consumo da carne é de domínio mais masculino, e o vegetarianismo, então, age como um sinal de doença da cultura patriarcal, expressa em três modos: na revelação da nulidade da carne, na nominação das relações e na recusa do consumo de carne e da cultura patriarcal.

É importante observar que o título da resenha propõe uma Teoria Feminista-Vegana, mas o livro é sobre uma teoria crítica feminista-vegetariana, como sugere o último capítulo. Optamos pelo termo feminismo-vegano, pois a palavra veganismo aparece no texto de Adams nos comentá rios da vigésima edição, isso está dado pelas condições de produção, já que a terminologia veganismo aparece na literatura acadêmica somente no final dos anos 1990. Quando o livro foi escrito, era comum a palavra vegetarianismo, que está relacionada à questão da alimentação e serve para diferenciar as pessoas que não comem nenhum tipo de carne, enquanto a palavra veganismo é mais ampla, significa a prática de não utilizar produtos derivados de animais não só na alimentação, mas também no vestuário, nos produtos domésticos, entre outros.

A obra é rica, embora a tradução deixe muito a desejar. Vale a pena comparar as duas edições: a original e a traduzida. Observamos, ao ler e analisar a tradução, comparando-a com o original, que, na capa do livro As políticas sexuais da carne, há uma ilustração que apareceu originalmente em uma toalha de praia em 1969, mostrando uma mulher dividida em cortes de "carne", como a imagem dos cortes da carne de vaca, e na qual se lia o subtítulo: "Qual é o seu corte?" Na tradução, a capa foi trocada por uma imagem com silhuetas femininas sensuais impressas em cima de um fundo preto e branco, que sugere o couro de uma vaca. A troca das imagens sugere, para nós, uma suavização no impacto das comparações entre a violência sexista e a especista, além disso, vai ao encontro dos interesses dos latifundiários nacionais, já que somos um dos maiores exportadores de carne no mundo.

Havia algumas imagens publicitárias internas no livro original que foram abortadas pelo editor da tradução, a sua ausência colabora para nosso argumento referente à capa, o que nos leva a pensar que essas imagens foram supridas no intuito de diminuir gastos gráficos ou por desinteresse do editor. De qualquer modo, a tradução e publicação do livro A Política Sexual da Carne torna mais acessível a discussão proposta por Adams e se transforma em uma ferramenta para se pensar as relações entre a opressão das mulheres e dos animais como baseadas na mesma hierarquia que sustenta o pensamento patriarcal.

Patrícia Lessa Universidade Estadual de Maringá Michelle Camargo Universidade Estadual de Campinas 